\title{
ASSESSMENT OF INDUSTRIAL BYPRODUCTS AS PERMEABLE REACTIVE BARRIERS FOR LANDFILL LEACHATE MANAGEMENT
}

\author{
Barjinder Bhalla ${ }^{1}$, M.S. Saini ${ }^{2}$, M.K. Jha ${ }^{3}$ \\ ${ }^{1}$ Scientist C, Pushpa Gujral Science City, Kapurthala- 144601, Punjab, India \\ ${ }^{2}$ Director, Guru Nanak Dev Engineering College, Ludhiana-141006, Punjab, India \\ ${ }^{3}$ Professor and Dean Academics, Department of Chemical Engineering, Dr.B.R.Ambedkar National Institute of \\ Technology (NIT), Jalandhar-144011, Punjab, India
}

\begin{abstract}
Laboratory scale studies were conducted to investigate the feasibility of Industrial by-products as potential alternative medium to conventional gravel in the drainage layer of leachate collection system as permeable reactive barriers (PRBs) for landfill leachate treatment. Industrial by-products were used to treat effectively the landfill leachate, which is an innovative in-situ remediation technology. This study will open a tremendous scope of using industrial byproducts as potential medium for treating leachate and this would reduce the magnitude of the current industrial waste disposal problem and convert one waste into a beneficial material. Industrial waste, such as Steel plant by-product (Waste slag), Tire industry by-product (scrap-tire-shreds) and Rice Sheller by-product (Rice husks) were studied. The availability and the cost are important criteria in selecting a reactive material. These Industrial waste materials are inexpensive and abundant, and are, therefore, ideal for low cost leachate treatment. Leachate treatment efficiency was evaluated on the basis of percentage reduction in concentration of leachate parameters before and after treatment by passing through Test Cells 1 to 11 having different combinations of conventional gravel and various Industrial by-products with total thickness 500 mm of PRBs (multibarrier). Treated leachate samples were collected from Test Cells 1 to 11 at the interval of 30, 60 and 90 days. The percentage reduction in various leachate parameters was maximum with Test Cell-11 having combination of rice husk (125 mm), waste slag $(125 \mathrm{~mm})$, scrap-tire-shreds $(125 \mathrm{~mm})$ and gravel layer $(125 \mathrm{~mm})$ in equal proportion as PRBs (multibarrier). It has been observed that leachate sample after passing through combined beds of Industrial by-products and conventional gravel gave better results in comparison to Test Cell-1 containing conventional gravel bed singly. This performance trend can be attributed due to combined effect of conventional gravel and Industrial by-products bed on adsorption, ion exchange reactions, filtration, precipitation and biological uptake. The percentage reduction in $\mathrm{BOD}_{5}, \mathrm{COD}$, Chloride $\left(\mathrm{Cl}^{-}\right)$, Nitrate $\left(\mathrm{NO}_{3}^{-}\right)$, Phosphorus $(\mathrm{P})$, Sulphate (SO $\left.{ }_{4}^{2-}\right)$ value was maximum upto $76.5 \%, 83.5 \%, 64.4 \%, 81.2 \%, 73.5 \%$ respectively. For reliable expectation on the longevity of PRBs (multibarrier), column test has to be performed for longer periods of time and the changes in material reactivity need to be observed.
\end{abstract}

Keywords: Permeable reactive barriers, Landfill, Leachate, Industrial byproducts, Test Cells

\section{INTRODUCTION}

Rapid growth of population and industrialization and other development activities during the past few decades have been responsible for environment pollution and resources degradation. Rapid urbanization has seriously enhances the problem of waste disposal and management. Industrial byproducts disposal remains a problematic issue in industrialized nations around the world. Huge quantity of Industrial byproducts are being generated every year and results in major environmental hazards worldwide. The present recycling techniques of the industrial byproducts may only consume a very small amount of the unwanted scrap. The percentage of industrial byproducts recycled is not compatible with the growth of unwanted scrap. This has become a serious problem in many countries. A large number of industrial byproducts are landfilled, stockpiled and illegally dumped. In order to avoid the continual addition of industrial byproducts to these unsightly and unhealthy stockpiles, innovative methods of recycling and reuse of industrial byproducts needs to be developed. Emphasis should be given on sound waste management strategy which includes waste minimization, recovery, recycling and reuse.

During the last decade of the 19th century, as well as during initial years of 20th century, millions of people died due to Bubonic Plague in India, which had linkages to poor management of solid waste. Solid waste management includes the control of generation, storage, collection, transfer and disposal of solid waste in an environmentally acceptable manner. The disposal of solid waste currently relies principally on landfilling. In India most landfills are usually open dumps/unlined landfills. Only a fraction can be regarded as engineered landfills (designed and constructed according to engineering specifications). Engineered landfills are constructed to include containment system and structure 
designed to protect the environment. These measures include lining systems, gas pipes, rain water collection control and monitoring boreholes. Landfilling continues to be the most common form of waste disposal despite the fact that leachate seriously contaminates water sources. Leachate is the liquid residue resulting from the various physical, chemical and biological processes taking place within the landfill. Landfill leachate is generated by excess rainwater percolating through the waste layers in a landfill. This liquid contains large number of organic and inorganic compounds. The leachate accumulates at the bottom of the landfill and percolates through the soil. Areas near landfills have a greater possibility of groundwater contamination because of the potential pollution source of leachate originating from the nearby site. Such contamination of groundwater resource poses a serious threat to the natural environment and human health [1,2]. The extensive size of many of these leachate contaminated groundwater plumes, covering several to hundreds of hectares [3], renders conventional ex-situ groundwater remediation techniques economically and technically unfeasible, due to the long treatment duration and huge costs in soil excavation, groundwater pumping and processing of the contaminated substances.

\subsection{Permeable Reactive Barriers (PRBs)}

The PRBs technology has generated a significant interest among researches. This is to due to the perceived cost/benefit ratio and the potential of PRBs to mitigate the spread of contaminants that have proven difficult and expensive to manage with other cleanup methods [4]. PRB is a continuous, permeable treatment zone designed to intercept and remediate a contaminant. The treatment zone may be created directly using reactive materials such as iron or indirectly using materials designed to stimulate secondary processes, such as by adding carbon substrate and nutrients to enhance microbial activity. In this way, contaminant treatment may occur through physical, chemical and biological processes. The phenomena, which help in remediation within PRBs, are adsorption/sorption, precipitation, oxidation/reduction and biodegradation. Recently, many researchers have introduced the PRBs system as an alternative technology to control leachate $[5,6,7,8,9,10,11,12,13,14,15,16]$. Multifunctional PRBs (multibarrier) was recently reported by Van Nooten et al. [17] as a semi-passive and innovative in-situ remediation technology to treat landfill leachate contamination. Fig. 1 shows schematic overview of the Multibarrier concept that was successfully designed for the semi-passive removal of ammonium, AOX, COD and toxicity from landfill leachate. A multibarrier combines different reactive materials and contaminant removal processes, which is necessary to remove a complex pollutant mixture such as landfill leachate contamination. PRBs which is an emplacement of reactive materials in the subsurface designed to intercept a contaminant plume, provides a flow path through the reactive media, and transform the contaminants into environmentally acceptable forms to attain remediation concentration goals down gradient of barrier [4]. They are considered a low cost, effective alternative for remediating contaminated sites. The technology of PRBs could potentially allow many more contaminated sites to be remediated effectively, thus greatly enhancing natural groundwater protection. Groundwater remediation using PRBs is an in situ method with low energy demand and therefore more cost-effective than standard remediation techniques [18]. It is a passive, in situ technology that has a high potential to treat shallow aquifers at a lower cost than traditional pumpand-treat methods, but due to a lack of long-term data, its costeffectiveness has not been proven $[19,20]$. However, Schad and Gratwohl [21] found that the remediation costs can be up to 50 percent less than pump-and-treat methods based on data collected at several sites. In addition, using PRBs reduces contaminant exposure to humans and allows the overlying land to be actively used during remediation. A wide variety of pollutants are degraded, precipitated, sorbed or exchanged in the reactive zone, including chlorinated solvents, heavy metals, radio nuclides and other organic and inorganic species [22,23]. Therefore, making PRBs cost-effective is imperative. In order to achieve this, experiments on low-cost reactive media is of utmost importance. The main engineering challenge is determination of suitable type and amount of reactive materials in a permeable wall and proper placement techniques. The availability and the cost are important criteria in selecting a reactive material. Continuing controlled column experiments for prolonged periods of time provides an opportunity to derive the treatment system [24].

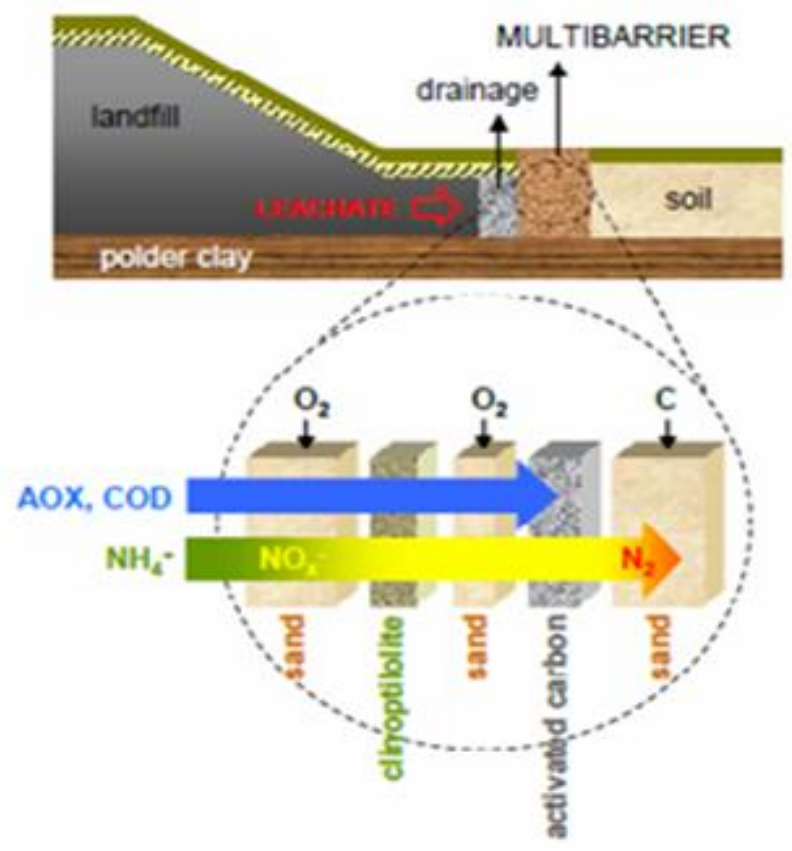

Fig-1: Schematic overview of the permeable reactive barriers (multibarrier) concept 
Several researchers have devoted their attention to the use of industrial byproducts for civil and environmental engineering applications. However, alternative materials are being explored that facilitate sustainability, are less expensive and may be less prone to fouling by mineral precipitates. Some industrial byproducts appear to have significant potential as low cost and effective reactive materials for PRBs used to treat number of contaminants. Large scale uses of shredded tires have been identified by several researchers for civil engineering applications, such as highway embankments, pavements, retaining structures and lightweight fill material. Economically and environmentally feasible alternatives have been investigated for recycling of waste scrap tires. One of these applications is the use of shredded scrap tires as drainage material in landfill system. Tire shreds can be used as an alternative to crushed stones (gravel) as drainage media in landfill leachate collection systems was supported by number of workers [25,26,27,28,29,30,31,32]. The use of shredded scrap tires as drainage material has the potential for the utilization of large quantities of scrap tires. Such use offers an economic advantage over conventional materials without compromising engineering performance in addition; this implementation utilizes the scrap tires as a valuable resource material and helps to alleviate the growing problems currently associated with the management and disposal of scrap tires. PRBs (multibarrier) is a sustainable technology for cleaning contaminated groundwater. PRBs with zero-valent iron as a reactive material could be one of the most promising technologies to remediate the contaminated groundwater $[33,34,35]$. Removal of contaminants in leachate from landfill by waste steel scrap and converter slag is the first investigation of it kind related to potential benefits of recycling industrial waste in controlling contaminants in leachate [36]. Feasibility studies related to other industrial byproducts as effective reactive materials for PRBs (multibarrier) and scope of MultiPermeable Reactive Barriers for leachate treatment needs to be investigated.

\subsection{Leachate Collection Layer (Drainage Layer)}

Leachate management can be achieved through effective control of leachate generation, its treatment and subsequent recycling. In India most landfills are open dumps/unlined landfills. Engineered landfill sites are provided with impermeable liner and drainage system at the base of the landfill, which will not allow leachate to percolate into subsoil. Optimal leachate treatment, in order to reduce the negative impact on the environment, is today's challenge.

Landfill design generally consists of three layers: the cover soil layer, the drainage layer and the barrier layer. Fig. 2 shows leachate drainage layer in MSW landfills [37]. The current practice of landfill design is to use granular soil ranging from fine sands to coarse gravels as the drainage material (also known as leachate collection layer) which is supported by number of studies $[25,26,27,29,37,38,39,40]$.
As per Ontario Ministry of Environment (MoE) [41] report of landfill standards a minimum thickness of $0.3 \mathrm{~m}(300 \mathrm{~mm})$ of granular drainage material is usually recommended for the drainage layer with a minimum of $0.5 \mathrm{~m}(500 \mathrm{~mm})$ at the location of perforated leachate collection pipes. In the present study, various industrial byproducts were introduced as potential alternative medium to conventional gravel in the drainage layer of leachate collection system as permeable reactive barriers for leachate treatment either singly or in combination.

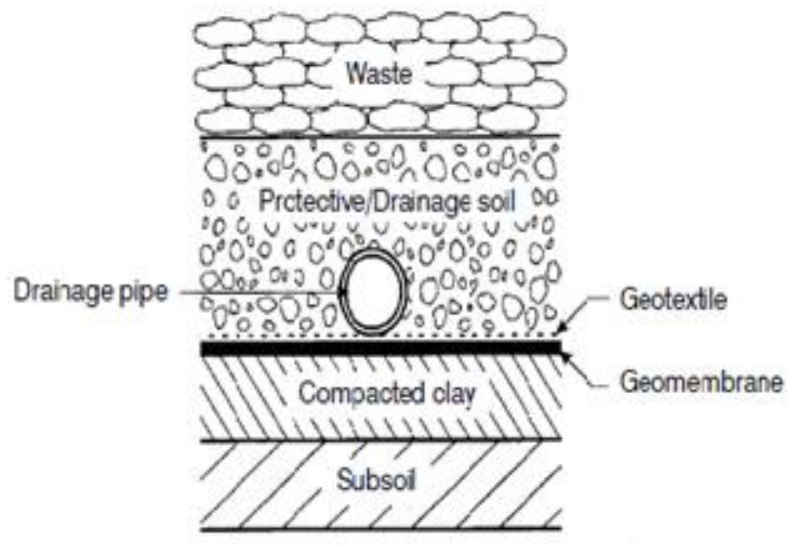

Fig- 2: Leachate drainage layer in MSW landfills

\subsection{Objective of the Study}

The present study is an effort to explore the potential benefits of recycling industrial waste in controlling contaminants in leachate. The aim of this study was to conduct laboratory scale investigations to study the feasibility of PRBs (multibarrier) with low-cost, locally and readily available Industrial byproducts to be used as a reactive material to treat effectively the landfill leachate, which is an innovative in-situ remediation technology to treat landfill leachate contamination. Industrial waste, such as Steel plant by-product (waste slag), Tire industry by-product (scrap-tire-shreds) and Rice Sheller byproduct (rice husks) were studied. These industrial waste materials are inexpensive and abundant, and are, therefore, ideal for low cost leachate treatment. Thus, the present study will open a tremendous scope of using industrial byproducts as potential medium for treating leachate and this would reduce the magnitude of the current industrial waste disposal problem and convert one waste into a beneficial material. Leachate treatment efficiency was evaluated on the basis of percentage reduction in concentration of leachate contaminants before and after treatment by passing through PRBs (multibarrier). In summary, there is perhaps no systemic study on the Industrial by-products as potential alternative medium to conventional gravel in the drainage layer of leachate collection system as permeable reactive barrier for leachate treatment. 


\section{MATERIALS AND METHODS}

\subsection{Study Location}

Ludhiana is the largest city in Punjab, both in terms of area and population. It lies between latitude $30^{\circ} 55^{\prime} \mathrm{N}$ and longitude $75^{0} 54^{\prime}$ E. The Municipal Corporation limit of city is spread over an area of $141 \mathrm{sq} . \mathrm{km}$. The population of the city within the Municipal Corporation area is estimated at 34,87,882 in 2011 [42]. The climate of Ludhiana is semi arid with maximum mean temperature reaching upto $42.8^{\circ} \mathrm{C}$ and minimum mean temperature is as below as $11.8^{0} \mathrm{C}$. Total rainfall during the year is $600-700 \mathrm{~cm} ; 70 \%$ of total rainfall occurs from July to September. The altitude varies from $230 \mathrm{~m}$ to $273 \mathrm{~m}$ from mean sea level [43]. Leachate sample for the present study was collected from Jamalpur landfill site of Ludhiana City, Punjab (Table1). Fig. 2 shows municipal solid waste heaps at Jamalpur landfill site. No cover of any description is placed over the spread waste to inhabit the ingress of surface water or to minimize litter blow and odours or to reduce the presence of vermin and insects. Rag pickers regularly set fire to waste to separate non-combustible materials for recovery. Since, there are no specific arrangements to prevent flow of water into and out of landfill site, the diffusion of contaminants released during degradation of landfill wastes, may proceed uninhibited. No proper compaction is done to compress the waste into the site.

Table- 1: Details of Jamalpur landfill site of Ludhiana City, Punjab (India)

\begin{tabular}{|l|l|l|}
\hline $\begin{array}{l}\text { Land area } \\
\text { (acres) }\end{array}$ & $\begin{array}{l}\text { Average depth } \\
\text { (in ft.) }\end{array}$ & $\begin{array}{l}\text { Future life } \\
\text { (years) }\end{array}$ \\
\hline 25 & 8 to 10 & 25 \\
\hline
\end{tabular}

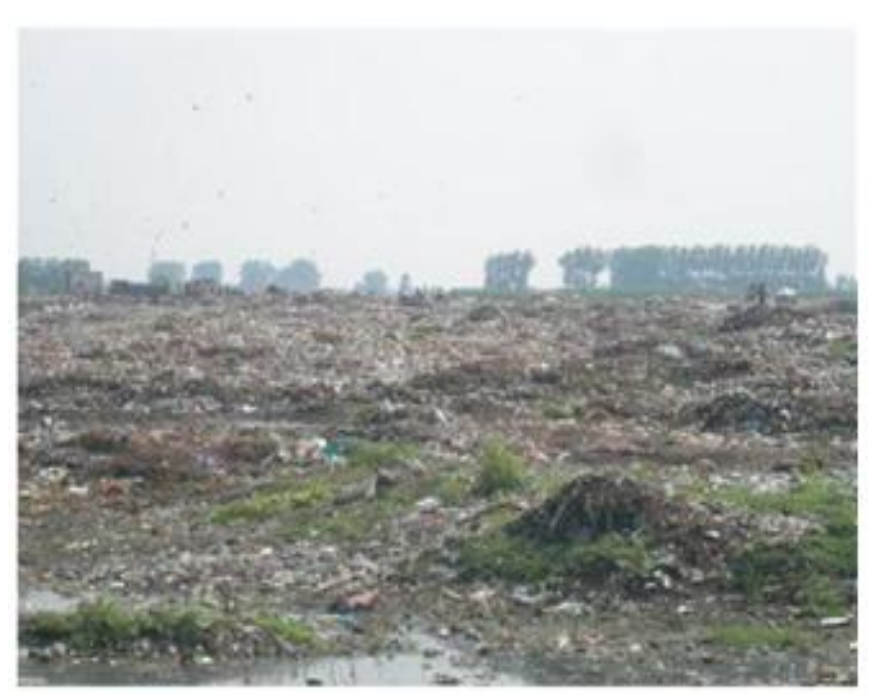

Fig- 3: Municipal solid waste heaps at Jamalpur landfill site of Ludhiana City, Punjab (January, 2012)

\subsection{Leachate Sampling}

Leachate sample was collected from landfill site on Tajpur Road at Jamalpur Village having 25 acres of low lying land area. This site is non-engineered low lying open dump. It has neither any bottom liner nor any leachate collection and treatment system. Therefore, all the leachate generated finds its paths into the surrounding environment. The landfill site is not equipped with any leachate collectors. To determine the quality of leachate, integrated samples were collected from different landfill locations. Leachate samples were collected from the base of solid waste heaps where the leachate was drained out by gravity. Leachate samples were collected in January end, 2012. Monitoring parameters were selected based on relative importance in municipal landfill leachate composition and their pollution potential on groundwater resources as per Municipal Solid Waste (Management and Handling) Rules, 2000 under the Environment Protection Act (EPA), 1986 by Ministry of Environment and Forests (MoEF), Govt. of India. Various leachate parameters viz Biological Oxygen Demand $\left(\mathrm{BOD}_{5}\right)$, Chemical Oxygen Demand (COD), Chloride $\left(\mathrm{Cl}^{-}\right)$, Nitrate $\left(\mathrm{NO}_{3}{ }^{-}\right.$, Phosphorus (P), Sulphate $\left(\mathrm{SO}_{4}{ }^{2-}\right)$ and heavy metals were analyzed to determine pollution potential of leachate discharge from municipal solid waste landfill site to estimate its pollution potential.

\subsection{Analytical Work}

Analytical methods were according to Standard methods for examination of water and wastewater specified by American Public Health Association [44]. Biological Oxygen Demand (BOD)-Winkler's method was used for estimating initial and final DO in the sample and BOD was determined (5210-B of Standard methods). Chemical Oxygen Demand (COD) was determined by refluxion of sample followed by titration with Ferrous Ammonium Sulphate (FAS) was adopted (5220.C: Standard Methods). Argentometric volumetric titration method in the presence of Potassium chromate was adopted for chloride (4500-Cl-.B of Standard Methods). Nitrate was analyzed by HACH Portable Spectrophotometer (DR 2800) by Cadmium Reduction Method (8039) adapted from Standard Methods at a wavelength of $450 \mathrm{~nm}$ [45]. Total Phosphorus was analyzed by HACH Portable Spectrophotometer (DR2800) by Molybdovanadate Method (10127) with Acid Persulfate digestion adapted from Standard Methods at a wavelength of $420 \mathrm{~nm}$ [45]. Sulphate was analyzed by $\mathrm{HACH}$ Portable Spectrophotometer (DR 2800) by SulfaVer 4 Method (8051) adapted from Standard Methods at a wavelength of $520 \mathrm{~nm}$ [45]. Heavy metals like Iron, Lead, Chromium, Cadmium, Copper, Zinc, Nickel and Arsenic were analyzed using ELICO double beam SL 210 UV-VIS Spectrophotometer [46]. 


\subsection{Laboratory Experimental Setup}

\section{Test Cells 1 to 11}

11 nos of Test Cells consisting of polyvinyl chloride cylinders (PVC) of height $1524 \mathrm{~mm}$ and diameter $152.3 \mathrm{~mm}$ were used in the laboratory for experimental work. Taps were drilled at the base of the Test Cells to collect treated leachate samples. Test Cells 1 to 11 were consisted of conventional gravel and various Industrial by-products beds of different combinations with total thickness $500 \mathrm{~mm}$ [41] in the drainage layer of leachate collection system as PRBs (multibarrier). Collected landfill leachate samples were passed through 11 nos of laboratory Test Cells having combined beds of Industrial byproducts (waste slag, scrap-tire-shreds and rice husks) and conventional gravel with this objective to find out the efficacy of Industrial by-products as potential alternative medium to conventional gravel in the drainage layer of leachate collection system as PRBs (multibarrier) for leachate treatment. The treatment was conducted without applying any stress on PRBs (multibarrier). The details of different combinations of conventional gravel and various Industrial by-products used in Test Cells were shown in Table 2.

Table-2: Details of Test Cells 1 to 11

\begin{tabular}{|c|c|c|c|c|c|c|c|c|c|}
\hline \multirow[t]{3}{*}{$\begin{array}{l}\text { Test } \\
\text { Cells }\end{array}$} & \multirow[t]{3}{*}{$\begin{array}{c}\text { Size of Test Cells } \\
\text { (mm) }\end{array}$} & \multicolumn{4}{|c|}{$\begin{array}{c}\text { Thickness of permeable reactive } \\
\text { barriers bed (mm) }\end{array}$} & \multicolumn{4}{|c|}{ Size range $(\mathrm{mm})$} \\
\hline & & \multicolumn{3}{|c|}{ Industrial by-products } & \multirow[t]{2}{*}{ Gravel } & \multicolumn{3}{|c|}{ Industrial by-products } & \multirow[t]{2}{*}{ Gravel } \\
\hline & & $\begin{array}{l}\text { Scrap- } \\
\text { tire- } \\
\text { shreds }\end{array}$ & $\begin{array}{l}\text { Waste } \\
\text { slag }\end{array}$ & $\begin{array}{l}\text { Rice } \\
\text { husks }\end{array}$ & & $\begin{array}{l}\text { Scrap- } \\
\text { tire- } \\
\text { shreds }\end{array}$ & $\begin{array}{l}\text { Waste } \\
\text { slag }\end{array}$ & $\begin{array}{c}\text { Rice } \\
\text { husks }\end{array}$ & \\
\hline 1 & \multirow{11}{*}{$\begin{array}{l}\text { Height }=1524 \\
\text { Diameter }=152.3\end{array}$} & 0 & 0 & 0 & 500 & \multirow[t]{11}{*}{$10-20$} & \multirow[t]{11}{*}{$10-20$} & \multirow[t]{11}{*}{$3-5$} & \multirow[t]{11}{*}{$10-20$} \\
\hline 2 & & 250 & 0 & 0 & 250 & & & & \\
\hline 3 & & 0 & 250 & 0 & 250 & & & & \\
\hline 4 & & 0 & 0 & 250 & 250 & & & & \\
\hline 5 & & 375 & 0 & 0 & 125 & & & & \\
\hline 6 & & 0 & 375 & 0 & 125 & & & & \\
\hline 7 & & 0 & 0 & 375 & 125 & & & & \\
\hline 8 & & 125 & 0 & 0 & 375 & & & & \\
\hline 9 & & 0 & 125 & 0 & 375 & & & & \\
\hline 10 & & 0 & 0 & 125 & 375 & & & & \\
\hline 11 & & 125 & 125 & 125 & 125 & & & & \\
\hline
\end{tabular}

The schematic representations of each Test Cells from 1 to 11 were shown in Fig. 4. There was a perforated plate over the media at the top of the Test Cells to distribute leachate evenly throughout the column and to prevent by-passing of water. All the reactive materials were washed and then dried before loading. The leachate was loaded into Test Cells with the help of shower. 15 litres of leachate sample was passed through each of the 11 laboratory Test Cells. Treated leachate samples were collected from taps at the base of the Test Cells. Leachate samples were collected from Test Cells 1 to 11 at the interval of 30, 60 and 90 days. Unsaturated conditions prevailed in all the Test Cells, the treatment mechanism was expected to be greatly similar to natural attenuation in the unsaturated zone of soil. However, these Test Cells differed from the unsaturated zone due to the presence of reactive media. Bagchi [47] identified following mechanisms of leachate attenuation in soil: adsorption, ion exchange reactions, dilution, filtration, precipitation and biological uptake. It was expected that these conditions would improve the attenuation of some parameters. Test Cells were opened at the top. Therefore at the upper 
layers, aerobic biodegradation was possible and at the middle and bottom layers both aerobic and anaerobic conditions exist.

\section{RESULTS AND DISCUSSION}

Laboratory studies were conducted to investigate Industrial byproducts (waste slag, scrap-tire-shreds and rice husks) as a potential alternative to conventional gravel in the drainage layer of leachate collection system at the base of landfill as PRBs (multibarrier) by comparative performance study of Test Cells consisting of different combination of conventional gravel and Industrial by-products (waste slag, scrap-tire-shreds and rice husks) as leachate collection layer. Best combination in terms of reduction in various leachate parameters after passing through Test Cells 1 to 11 has been identified. Leachate samples were analyzed for various parameters viz Biological Oxygen Demand $\left(\mathrm{BOD}_{5}\right)$, Chemical Oxygen Demand (COD), Chloride $\left(\mathrm{Cl}^{-}\right)$, Nitrate $\left(\mathrm{NO}_{3}{ }^{-}\right)$, Phosphorus $(\mathrm{P})$, Sulphate $\left(\mathrm{SO}_{4}{ }^{2-}\right)$ and the results indicated that all the parameters were beyond USEPA permissible limits. Heavy metals viz Iron, Lead, Chromium, Cadmium, Copper, Zinc, Nickel and Arsenic values for leachate were in trace amount as the waste is domestic in nature.

The comparative performance study of Test Cells- 1 to 11 has been expressed in terms of percentage reduction of various parameters. Fig.5 (a-f) showed percentage reduction in various leachate parameters after passing through Test Cells- 1 to 11 having bed of different combinations of conventional gravel and Industrial by-products (waste slag, scrap-tire-shreds and rice husk). The percentage reduction in various leachate parameters was maximum with Test Cell-11 having combination of rice husks $(125 \mathrm{~mm})$, waste slag $(125 \mathrm{~mm})$, scrap-tire-shreds $(125 \mathrm{~mm})$ and conventional gravel layer (125 $\mathrm{mm}$ ) in equal proportion as PRBs (multibarrier) followed by Test Cell-7 having combination of rice husks $(375 \mathrm{~mm})$ and conventional gravel layer $(125 \mathrm{~mm})$ followed by Test Cell-6 having combination of waste slag $(125 \mathrm{~mm})$ and conventional gravel layer $(125 \mathrm{~mm})$ followed by Test Cell-5 having combination of scrap-tire-shreds $(375 \mathrm{~mm})$ and conventional gravel layer $(125 \mathrm{~mm})$ followed by Test Cell-4 having combination of rice husks $(250 \mathrm{~mm})$ and conventional gravel layer $(250 \mathrm{~mm})$ in equal proportion followed by Test Cell-3 having combination of waste slag $(250 \mathrm{~mm})$ and conventional gravel layer $(250 \mathrm{~mm})$ in equal proportion followed by Test Cell-2 having combination of scrap-tire-shreds $(250 \mathrm{~mm})$ and conventional gravel layer $(250 \mathrm{~mm})$ in equal proportion followed by Test Cell-10 having combination of rice husks $(125 \mathrm{~mm})$ and conventional gravel layer $(375 \mathrm{~mm})$ followed by Test Cell-9 having combination of waste slag $(125 \mathrm{~mm})$ and conventional gravel layer $(375 \mathrm{~mm})$ followed by Test Cell-8 having combination of scrap-tire-shreds $(125 \mathrm{~mm})$ and conventional gravel layer $(375 \mathrm{~mm})$ and followed by Test Cell1 containing conventional gravel layer singly $(500 \mathrm{~mm})$. The data presented in this study indicated that with the passage of time at the interval of 30,60 and 90 days percentage reduction in various parameters of leachate samples values increased.

This performance trend can be attributed due to combined effect of conventional gravel and Industrial by-products bed (waste slag, scrap-tire-shreds and rice husks) on adsorption, ion exchange reactions, filtration, precipitation and biological uptake. It is hypothesized that introduction of Industrial byproducts in gravel layer enhances the uniformity of the permeating leachate and thus increases both the amount of surface area and contact time available for sorption. Industrial by-products (waste slag, scrap-tire-shreds and rice husks) provide greater surface area for the sorption of various waste constituents from the leachate. Test Cell-1 with only conventional gravel layer contains fewer interconnecting voids for fluid movements; flow is limited and restricted to only a few flow channels in comparison to Industrial by-products layer as a result less surface area for sorption is available. Sorption refers to the exchange of molecules and ions between the solid phase and the liquid phase [48]. Hence, vacant sites for adsorption decrease with time leading to lesser sites for adsorption to take place. Biodegradation takes some time to execute because it needs the synthesis of microorganisms. It implies that the dominant treatment mechanism of biodegradable portion of organic matter could be biological uptake. In fact the percentage removal increased with time confirms that the major mechanism of removal could be biodegradation since the rate of removal by adsorption is rapid at the beginning and decreases with time. Leachate sample after passing through combined beds of gravel and Industrial by-products (waste slag, scrap-tire-shreds and rice husks) gave better results in comparison to Test Cell- 1 containing gravel bed when used singly. The present study indicates that Industrial by-products (waste slag, scrap-tire-shreds and rice husks) can be used as a potential alternative to conventional gravel in the drainage layer of leachate collection system as PRBs (multibarrier) by improving upon the reduction in the various leachate parameters of environmental concern. The following sub sections show the status of percentage reduction in the various leachate parameters viz Biological Oxygen Demand $\left(\mathrm{BOD}_{5}\right)$, Chemical Oxygen Demand (COD), Chloride $\left(\mathrm{Cl}^{-}\right)$, Nitrate $\left(\mathrm{NO}_{3}^{-}\right)$, Phosphorus $(\mathrm{P})$, Sulphate $\left(\mathrm{SO}_{4}{ }^{2-}\right)$ by laboratory scale Test Cells with reactive media.

\subsection{Removal of $\mathrm{BOD}_{5}$}

$\mathrm{BOD}_{5}$ value of the leachate sample collected from landfill site was $495 \mathrm{mg} / \mathrm{l}$. The measured $\mathrm{BOD}_{5}$ value of leachate sample was considerably higher than the standard limit. $\mathrm{BOD}_{5}$ is the measure of biodegradable organic mass of leachate and that indicates the maturity of the landfill which typically decreases with time [49]. Adsorption and biological uptake could be the dominant treatment mechanisms of organic matter. Percentage reduction in $\mathrm{BOD}_{5}$ value of the treated leachate samples collected from Test Cells-1 to 11 after 30 days were 10.5\%, $16.8 \%, 19.8 \%, 22.6 \%, 27.8 \%, 30.7 \%, 36.9 \%, 12.1 \%, 13.7 \%$, 
$14.3 \%$ and $40.5 \%$, after 60 days were $15.9 \%, 23.6 \%, 27.3 \%$, $31.4 \%, 36.2 \%, 42.4 \%, 48.2 \%, 16.6 \%, 18.1 \%, 21.8 \%$ and $53.9 \%$ and after 90 days were $25.4 \%, 35.6 \%, 39.2 \%, 47.8 \%$, $50.9 \%, 55.7 \%, 65.1 \%, 27.8 \%, 30.3 \%, 33.8 \%$ and $76.5 \%$ as shown in Fig. 5(a). Percentage reduction in $\mathrm{BOD}_{5}$ value after passing through Test Cell-11 having combine bed of rice husks (125 mm), waste slag $(125 \mathrm{~mm})$, scrap-tire-shreds $(125 \mathrm{~mm})$ and conventional gravel layer $(125 \mathrm{~mm})$ in equal proportion as PRBs (multibarrier) gave better results in comparison to others. The percentage reduction in $\mathrm{BOD}_{5}$ value was $40.5 \%$ after 30 days, $53.9 \%$ after 60 days and $76.5 \%$ after 90 days. The percentage reduction in $\mathrm{BOD}_{5}$ values increased rapidly with time.

\subsection{Removal of COD}

COD value of the leachate sample collected from landfill site was $2535 \mathrm{mg} / \mathrm{l}$. The measured COD value of leachate sample was considerably higher than the standard limit. Bagchi [47] stated that the most important mechanism of COD attenuation in soil is biological uptake and filtration is a minor mechanism. According to the same author, the surfaces of organic matter provide some adsorption sites; in addition they may serve as energy source for microorganisms. Activated carbon is used to remove a portion of the remaining dissolved organic matter after secondary treatments [48]. Therefore, adsorption can also be considered a potential removal mechanism of organic materials in the columns with organic reactive media. Percentage reduction in COD value of the treated leachate samples collected from Test Cells-1 to 11 after 30 days were $11.2 \%, 21.4 \%, 25.5 \%, 28.1 \%, 33.5 \%, 40.7 \%, 49.5 \%, 13.4 \%$, $14.5 \%, 18.2 \%$ and $55.8 \%$ after 60 days were $16.8 \%, 28.6 \%$, $32.1 \%, 39.8 \%, 46.1 \%, 53.2 \%, 61.3 \%, 18.8 \%, 20.9 \%, 24.2 \%$ and $69.2 \%$ and after 90 days were $28.6 \%, 49.2 \%, 54.6 \%$, $60.2 \%, 65.3 \%, 70.4 \%, 75.2 \%, 32.7 \%, 39.3 \%, 43.6 \%$ and $83.5 \%$ as shown in Fig. 5(b). Percentage reduction in COD value after passing through Test Cell-11 having combine bed of rice husks $(125 \mathrm{~mm})$, waste slag $(125 \mathrm{~mm})$, scrap-tire-shreds $(125 \mathrm{~mm})$ and conventional gravel layer $(125 \mathrm{~mm})$ in equal proportion as PRBs (multibarrier) gave better results in comparison to others. The percentage reduction in COD value was $55.8 \%$ after 30 days, $69.2 \%$ after 60 days and $83.5 \%$ after 90 days. The percentage reduction in COD values increased rapidly with time.

\subsection{Removal of Chloride}

Chloride value of the leachate sample collected from landfill site was $1836 \mathrm{mg} / \mathrm{l}$. The measured chloride value of the leachate sample was considerably higher than the standard limit. Chloride is not attenuated by any soil type and is highly mobile under all conditions [49]. Dilution is the only mechanism for of attenuation of chloride in soil [47]. However the opposite of above statements happened in these columns because they had organic matter that increased the adsorption. Percentage reduction in chloride value of the treated leachate samples collected from Test Cells-1 to 11 after 30 days were
$11.4 \%, 16.5 \%, 18.4 \%, 20.1 \%, 22.6 \%, 28.1 \%, 31.6 \%, 12.7 \%$, $13.8 \%, 15.5 \%$ and $37.9 \%$ then after 60 days were $14.1 \%$, $20.9 \%, 22.5 \%, 25.2 \%, 30.3 \%, 36.8 \%, 42.1 \%, 15.2 \%, 16.3 \%$, $18.7 \%$ and $50.3 \%$ and after 90 days were $20.5 \%, 32.6 \%$, $35.7 \%, 39.4 \%, 42.6 \%, 48.4 \%, 53.9 \%, 23.9 \%, 27.5 \%, 30.2 \%$ and $64.4 \%$ as shown in Fig. 5(c). Percentage reduction in chloride value after passing through Test Cell-11 having combine bed of rice husks $(125 \mathrm{~mm})$, waste slag $(125 \mathrm{~mm})$, scrap-tire-shreds $(125 \mathrm{~mm})$ and conventional gravel layer (125 $\mathrm{mm}$ ) in equal proportion as PRBs (multibarrier) gave better results in comparison to others. The percentage reduction in chloride value was $37.9 \%$ after 30 days, $50.3 \%$ after 60 days and $64.4 \%$ after 90 days. The percentage reduction in chloride values increased rapidly with time.

\subsection{Removal of Nitrate}

Nitrate value of the leachate sample collected from landfill site was $18.6 \mathrm{mg} / \mathrm{l}$. The measured nitrate value of leachate sample was considerably higher than the standard limit. According to Bagchi [47], the major attenuation mechanism of nitrate is biological uptake. Microbial decomposition of organic carbon influences on many processes of the nitrogen cycle. With time, nitrogen concentration decreased due to microbial utilization of nitrate compounds and denitrifying as ammonia gas. Nitrate is the primary contaminant that leaches into groundwater. Percentage reduction in nitrate value of the treated leachate samples collected from Test Cells-1 to 11 after 30 days were $20.1 \%, 34.5 \%, 38.6 \%, 40.8 \%, 44.6 \%, 50.5 \%, 54.5 \%, 22.3 \%$, $25.1 \%, 30.2 \%$ and $63.4 \%$ after 60 days were $27.2 \%, 42.9 \%$, $45.2 \%, 49.9 \%, 56.5 \%, 61.2 \%, 66.8 \%, 32.8 \%, 30.4 \%, 38.5 \%$ and $76.8 \%$ and after 90 days were $40.6 \%, 53.8 \%, 56.8 \%$, $61.5 \%, 67.1 \%, 72.4 \%, 75.2 \%, 45.9 \%, 48.5 \%, 50.6 \%$ and $81.2 \%$ as shown in Fig. 5(d). Percentage reduction in nitrate value after passing through Test Cell-11 having combine bed of rice husks $(125 \mathrm{~mm})$, waste slag $(125 \mathrm{~mm})$, scrap-tire-shreds $(125 \mathrm{~mm})$ and conventional gravel layer $(125 \mathrm{~mm})$ in equal proportion as PRBs (multibarrier) gave better results in comparison to others. The percentage reduction in nitrate value was $63.4 \%$ after 30 days, $76.8 \%$ after 60 days and $81.2 \%$ after 90 days. The percentage reduction in nitrate values increased rapidly with time.

\subsection{Removal of Phosphorus}

Phosphorus value of the leachate sample collected from landfill site was $83.5 \mathrm{mg} / \mathrm{l}$. The measured phosphorus value of the leachate sample was considerably higher than the standard limit. Phosphorus is one of the key elements necessary for growth of plants and animals and is a backbone of the Kreb's Cycle and Deoxyribonucleic acid (DNA). Phosphorus transported from agricultural lands to surface water can promote eutrophication, which is one of the leading water quality issues in lakes and reservoirs. Percentage reduction in phosphorus value of the treated leachate samples collected from Test Cells-1 to 11 after 30 days were $18.6 \%, 29.1 \%$, $33.8 \%, 35.5 \%, 37.8 \%, 42.3 \%, 49.7 \%, 20.9 \%, 23.7 \%, 27.3 \%$ 
and $53.2 \%$ after 60 days were $23.3 \%, 36.9 \%, 40.2 \%, 43.8 \%$, $48.1 \%, 53.4 \%, 57.5 \%, 26.8 \%, 30.3 \%, 32.6 \%$ and $65.6 \%$ and after 90 days were $35.2 \%, 52.2 \%, 55.7 \%, 58.3 \%, 63.4 \%$, $68.6 \%, 72.1 \%, 33.6 \%, 40.3 \%, 46.8 \%$ and $79.8 \%$ as shown in Fig.5(e). Percentage reduction in phosphorus value after passing through Test Cell-11 having combine bed of rice husks (125 mm), waste slag (125 mm), scrap-tire-shreds $(125 \mathrm{~mm})$ and conventional gravel layer $(125 \mathrm{~mm})$ in equal proportion as PRBs (multibarrier) gave better results in comparison to others. The percentage reduction in phosphorus value was $53.2 \%$ after 30 days, $65.6 \%$ after 60 days and $79.8 \%$ after 90 days. The percentage reduction in phosphorus values increased rapidly with time.

\subsection{Removal of Sulphate}

Sulphate value of the leachate sample collected from landfill site was $65.1 \mathrm{mg} / \mathrm{l}$. The measured sulphate value of the leachate sample was considerably higher than the standard limit. The sulphate content of leachate mainly depends on the decomposition of organic matter present in the solid wastes. It is expected to decrease with refuse age. This decrease is caused by the reduction of sulphate to sulphide coincident with the initiation of anaerobic conditions in the landfill [48]. Thus, the sulphate concentration in leachate can also be used as an indicator of waste stabilization within landfill. Percentage reduction in sulphate value of the treated leachate samples collected from Test Cells-1 to 11 after 30 days were $16.3 \%$, $30.2 \%, 32.8 \%, 36.4 \%, 40.3 \%, 44.9 \%, 48.7 \%, 20.2 \%, 23.6 \%$, $61.7 \%$ and $56.5 \%$ after 60 days were $21.2 \%, 38.9 \%, 40.6 \%$, $43.9 \%, 48.8 \%, 52.6 \%, 55.2 \%, 28.3 \%, 31.4 \%, 35.4 \%$ and $62.3 \%$ and after 90 days were $33.1 \%, 50.8 \%, 53.9 \%, 57.7 \%$, $60.5 \%, 63.4 \%, 69.1 \%, 39.6 \%, 42.1 \%, 47.5 \%$ and $73.5 \%$ as shown in Fig. 5(f). Percentage reduction in sulphate value after passing through Test Cell-11 having combine bed of rice husks (125 mm), waste slag (125 mm), scrap-tire-shreds $(125 \mathrm{~mm})$ and conventional gravel layer $(125 \mathrm{~mm})$ in equal proportion as PRBs (multibarrier) gave better results in comparison to others. The percentage reduction in sulphate value was $56.5 \%$ after 30 days, $62.3 \%$ after 60 days and $73.5 \%$ after 90 days. The percentage reduction in sulphate values increased rapidly with time.

\section{CONCLUSIONS}

The following conclusions were drawn from the present study;

- In the laboratory scale column experiment, different degrees of contaminant removal were shown by different Test Cells-1 to 11 having different combination of reactive media, Industrial by-products (waste slag, scraptire-shreds and rice husks). The percentage reduction in $\mathrm{BOD}_{5}, \mathrm{COD}$, Chloride $\left(\mathrm{Cl}^{-}\right)$, Nitrate $\left(\mathrm{NO}_{3}{ }^{-}\right)$, Phosphorus (P), Sulphate $\left(\mathrm{SO}_{4}{ }^{2-}\right)$ value was maximum upto $76.5 \%$, $83.5 \%, 64.4 \%, 81.2 \%, 73.5 \%$ respectively.

- Unsaturated conditions prevailed in all the Test Cells, the treatment mechanism was expected to be greatly similar to natural attenuation in the unsaturated zone of soil.
However, these Test Cells differed from the unsaturated zone due to the presence of reactive media. Bagchi [47] identified following mechanisms of leachate attenuation in soil: adsorption, cation and anion exchange reactions, dilution, filtration, precipitation and biological uptake.

- The percentage reduction in various leachate parameters was maximum with Test Cell-11 having combination of rice husks $(125 \mathrm{~mm})$, waste slag $(125 \mathrm{~mm})$, scrap-tireshreds $(125 \mathrm{~mm})$ and conventional gravel layer $(125 \mathrm{~mm})$ in equal proportion as PRBs (multibarrier) followed by Test Cell-7 having combination of rice husks $(375 \mathrm{~mm})$ and conventional gravel layer $(125 \mathrm{~mm})$ followed by Test Cell-6 having combination of waste slag $(125 \mathrm{~mm})$ and conventional gravel layer $(125 \mathrm{~mm})$ followed by Test Cell-5 having combination of scrap-tire-shreds $(375 \mathrm{~mm})$ and conventional gravel layer $(125 \mathrm{~mm})$ followed by Test Cell-4 having combination of rice husks $(250 \mathrm{~mm})$ and conventional gravel layer $(250 \mathrm{~mm})$ in equal proportion followed by Test Cell-3 having combination of waste slag $(250 \mathrm{~mm})$ and conventional gravel layer $(250 \mathrm{~mm})$ in equal proportion followed by Test Cell-2 having combination of scrap-tire-shreds $(250 \mathrm{~mm})$ and conventional gravel layer $(250 \mathrm{~mm})$ in equal proportion followed by Test Cell-10 having combination of rice husks $(125 \mathrm{~mm})$ and conventional gravel layer $(375 \mathrm{~mm})$ followed by Test Cell-9 having combination of waste slag $(125 \mathrm{~mm})$ and conventional gravel layer $(375 \mathrm{~mm})$ followed by Test Cell- 8 having combination of scrap-tireshreds $(125 \mathrm{~mm})$ and conventional gravel layer $(375 \mathrm{~mm})$ and Test Cell-1 containing conventional gravel layer singly $(500 \mathrm{~mm})$.

- This performance trend can be attributed due to combined effect of conventional gravel and Industrial by-products bed (waste slag, scrap-tire-shreds and rice husks) on adsorption, cation and anion exchange reactions, filtration, precipitation and biological uptake. It is hypothesized that introduction of Industrial by-products in conventional gravel layer enhances the uniformity of the permeating leachate and thus increases both the amount of surface area and contact time available for sorption. Industrial by-products (waste slag, scrap-tireshreds and rice husks) provide greater surface area for the sorption of various waste constituents from the leachate. Test Cell-1 with only gravel layer contains fewer interconnecting voids for fluid movements; flow is limited and restricted to only a few flow channels in comparison to Industrial by-products layer as a result less surface area for sorption is available. Sorption refers to the exchange of molecules and ions between the solid phase and the liquid phase [48]. Hence vacant sites for adsorption decrease with time leading to lesser sites for adsorption to take place. Biodegradation takes some time to execute because it needs the synthesis of microorganisms. It implies that the dominant treatment mechanism of biodegradable portion of organic matter could be biological uptake. The percentage removal 
increased with time confirms that the major mechanism of removal could be biodegradation. The rate of removal by adsorption is rapid at the beginning and decreases with time. Leachate sample after passing through combined beds of conventional gravel and Industrial by-products (waste slag, scrap-tire-shreds and rice husks) gave better results in percentage reduction in various leachate parameters in comparison to Test Cell containing conventional gravel bed when used singly.

- The reactivity of the organic materials depends on the ability or availability of the contained carbon and according to the study of Waybrant et al. [50], the combination of more than one organic source is more successful than the use of solely one material. This is due to the fact that a mixture of organic materials contains compounds with varying complexity, some of them decomposing fast and others in a long time period, thus achieving long term reactivity of the barrier.

- For reliable expectation on the longevity of PRBs, column test has to be performed for longer periods of time and the changes in material reactivity need to be observed.

- In summary, there is perhaps no systemic study on the Industrial by-products as potential alternative medium to conventional gravel in the drainage layer of leachate collection system as permeable reactive barriers for leachate treatment. The present study is an effort to explore the potential benefits of recycling industrial waste in controlling contaminants in leachate.

\section{REFERENCES}

[1] A. Ding, Z. Zhang, J. Fu and L. Cheng, Biological control of leachate from municipal landfills, Chemosphere, 44, 2001, 1-8.

[2] P. Kjeldsen, M.A. Barlaz, A.P. Rooker, A. Baun, A. Ledin and T.H. Christensen, Present and long-term composition of MSW landfill leachate: a review, Crit. Rev. Environ. Sci. Technol., 32, 2002, 297-336.

[3] T.H. Christensen, P. Kjeldsen, P.L. Bjerg, D.L. Lensen, J.B. Christensen, A. Baun, H.J. Albrechtsen and G. Heron, Biogeochemistry of landfill leachate plumes, Appl.Geochem., 16, 2001, 659-718.

[4] USEPA, Permeable reactive barrier technologies for contaminant remediation, EPA/600/R-98/125, 1998, 17.

[5] S.R. Day and S.F. O'Hannesin, Geotechnical Tech niques for the construction of reactive barriers, Journal of Hazardous Materials, 67(3): 1999, 285-297.

[6] K.R. Waybrant, C.J. Ptacek and D.W. Blowes, Treatment of mine drainage using permeable reactive barriers: column experiments, Journal of Environ. Sci. Technol, 36, 2002, 1349-1356.

[7] Lee Jai-Young, Moon Chul-Hwan, Kim Jung-Hoon, Oh Byung-Taek, Feasibility study of the bio-barrier with biologically active tire rubbers for treating chlorinated hydrocarbons, Geo Science Journal, 11(2), 2007, 93184.

[8] B.T. Oh, B.T. Lee and J.Yoon, Removal of contaminants in leachate from landfill by waste steel scrap and converter slag, Environ Geochem Health, 29(4), 2007, 331-336.

[9] Halk Chung, Sang Keun Kim, Yong Soo Lee, Jun Yu, Permeable reactive barrier using atomized slag material for treatment of contaminants from landfills, Geosciences Journal, 11(2), 2007, 137-145.

[10] J. Fronczyk and K. Garbulewski, Selection of material suitable for permeable reactive barriers in the vicinity of landfills, Department of Geotechnical Engineering, Warsaw University of Life Sciences, Land Reclamation, 41, 2009, 3-9.

[11] Lee Jai-Young, Lee Kui-Jae, Youm Sun Young, Lee Mi-Ran, Seralathan Kamala-Kannan and Oh. Byung-Taek, Stability of multi-permeable reactive barriers for long term removal of mixed contaminants, Bulletin of Environmental Contamination and Toxicology, 84(2), 2009, 250-254.

[12] D. Jun, Z. Yongsheng and Hong Mei, Laboratory study on sequenced permeable reactive barrier remediation for landfill leachate contaminated groundwater, Journal of Hazardous Materials, 161, 2009, 224-230.

[13] D.H.Phillips, Permeable reactive barriers (PRBs): A sustainable technology for cleaning contaminated groundwater in developing countries, Environmental Engineering Research Centre, School of Planning, Architecture and Civil Engineering, Queen's University of Belfast, Belfast, United Kingdom, Desalination, 251, 2010, 352-359.

[14] Baric Massimiliano, Majone Mauro, Beccari Mario, Papini Marco Petrangeli, Coupling of polyhydroxy butyrate (PHB) and zero valent iron (ZVI) for enhanced treatment of chlorinated ethanes in permeable reactive barriers (PRBs), Chemical Engineering Journal,195196,2012,22-30.

[15] Liu Tingyi, Yang Xi, Wang Zhong-Liang, Xiaoxing Yan, Enhanced chitosan beads-supported $\mathrm{Fe} 0$-nano particles for removal of heavy metals from electroplating wastewater in permeable reactive barriers, Water Research, 47(17), 2013, 6691-6700.

[16] W. Amos Philip and L. Younger Paul, Substrate characterization for a subsurface reactive barrier to treat colliery spoil leachate, Water Research, 37(1), 2003, 108-120.

[17] Van Nooten, T. Diels and L. Bastiaens, Design of a multifunctional permeable reactive barrier for the treatment of landfill leachate contamination: laboratory column evaluation, Environ. Sci. Technol. 42, 2008, 8890-8895.

[18] C. Manz and K.Quinn, Permeable reactive barriers for the interception and treatment of acid mine drainage in groundwater at a mine site near Sudbury, Canada, 1997. 
[19] D.L.Naftz, S.J. Morrison, J.A. Davis and C.C. Fuller, Handbook of groundwater remediation using permeable reactive barriers: applications to radio nuclides, trace metals and nutrients, Academic Press, New York, 2002.

[20] K.E. Roehl, K. Czurda, T. Meggyes, F. Simon and D.I. Stewart, Long-term performance of permeable reactive barriers, Elsevier Science Publisher, New York, 2005

[21] H. Schad and P. Gratwohl, Funnel and gate systems for in situ treatment of contaminated groundwater at former manufactured gas plant sites, treatment walls and permeable reactive barriers, NATO CCMS, Vienna, 229, 1998, 56-65.

[22] R.W. Puls, C. Paul and R.M. Powell, The application of in situ permeable reactive (zero-valent iron) barrier technology for the remediation of chromatecontaminated groundwater: a field test, Applied Geochemistry, 14, 1999, 989-1000.

[23] USEPA, Permeable reactive subsurface barriers for the interception and remediation of chlorinated hydrocarbon and chromium (VI) plumes in ground water, EPA/600/f-97/008, 4, 1997.

[24] R. Blowes, C.J. Ptacek and J.L. Jambor, In-situ remediation of $\mathrm{Cr}(\mathrm{VI})$ - contaminated groundwater using permeable reactive walls: laboratory studies, Journal of Environmental Science \& Technology, 31 (12), 1997,3348-3357.

[25] D.N.Humphrey and W.P. Manion, Properties of tire chips for lightweight fill, grouting, soil improvement and geosynthetics, Proc., of the Conference Sponsored by the Geotechnical Engineering Division of the American Society of Civil Engineers 2, New Orleans, 1992, 1344-1355.

[26] D.P. Duffy, Using tire chips as a leachate drainage layer, Waste Age, 26, 1995, 113-122.

[27] R.Donovan, J.Dempsey and S. Owen, Scrap tire utilization in landfill applications. Proc., Solid Waste Association of North America, Wastecon GR-G 0034, 1996, 353-383.

[28] California Integrated Waste Management Board, Tire shreds as leachate drainage material at municipal solid waste landfill -Guidance Manual, 1998.

[29] Geosyntec Consultants, Guidance manual - Tire shreds as leachate drainage material at municipal solid waste landfill, Prepared for California Integrated Waste Mgmt. Board, 1998.

[30] D.N. Humphrey, Civil engineering applications of tire shreds. Proc. of the Tire Industry Conference, Clemson University, 1999, 1-16.

[31] A.H.Aydilek, E.T. Madden, and M.M. Demirkan, Field evaluation of a leachate collection system constructed with scrap tires, Journal of Geotechnical and Geoenvironmental Engineering, 132(8), 2006, 9901000 .

[32] K.R.Reddy, T.D. Stark, and A. Marella, Beneficial use of shredded tires as drainage material in cover systems for abandoned landfills, Periodical of Hazardous, Toxic and Radioactive Waste Management, 14(1), 2010, 4760.

[33] M.M.Scherer, S. Richter, R. L. Valentine, and P.J. Alvarez, Chemistry and microbiology of permeable reactive barriers for in situ groundwater clean up, Critical Reviews in Environmental Science and Technology, 26(4), 2000, 363-411.

[34] B.T. Oh, C.L. Just and P.J.J.Alvarez, Hexa hydro-1,3,5trinitro-1,3,5-triazine mineralization by zero valent iron and mixed anaerobic cultures, Environmental Science and Technology, 35(21), 2001, 4341-4346.

[35] B.T. Oh and P.J.J. Alvarez, Hexahydro-1,3,5-trinitro1,3,5-triazine (RDX) degradation in biologically-active iron column, Water, Air, and Soil Pollution, 141, 2002, 325-335.

[36] B.T. Oh, J.Y.Lee, J.Yoon, Removal of contaminants in leachate from landfill by waste steel scrap and converter slag, Department of Environmental Sciences and Biotechnology, Hallym University, South Korea, Environ Geochem Health, 29(4), 2007, 331-6.

[37] K.R.Reddy and R.E.Saichek, Characterization and performance assessment of shredded scrap tires as leachate drainage material in landfills, Proceedings of the fourteenth international conference on Solid Waste Technology and Management, Philadelphia, PA., 1998.

[38] K.R.Reddy, S.J.Baddi, M.Finy and J. Siebken, Field evaluation of protective cover soils for landfill geomembrane liners under construction loading, Geosynthetics International, 3(6), 1996, 679-700.

[39] ASTM. Standard practice for use of scrap tires in civil engineering applications, ASTM D6270-98. Annual book of ASTM standards: Environmental Assessment, American Society for Testing and Materials, W. Conshohocken, PA., 2002.

[40] C.E. Pierce and M.C. Blackwell, Potential of scrap tire rubber as light weight aggregate in flowable fill, Waste Management, 23, 2003, 197-208.

[41] Ministry of Environment (MOE), Landfill standards - a guideline on the regulatory and approval requirements for new or expanding landfilling sites, Ontario Ministry of the Environment, 1998, 1-127.

[42] www.census2011.co.in/census/district/594 -ludh.html

[43] Vision 2021, Ludhiana City Development Plan, Municipal Corporation, Ludhiana initiative under Jawaharlal Nehru National Urban Renewal Mission.

[44] APHA, Standard methods for the examination of water and wastewater. 21st edition, American Public Health Association, American Water Works Association, Water Environment Federation Publication, Washington, DC.,2005.

[45] Manual of HACH Portable Spectrophotometer (DR 2800).

[46] Manual of ELICO double beam SL 210 UV-VIS Spectrophotometer.

[47] A. Bagchi, Design of Landfills and Integrated solid waste management, John Wiley \& Sons, Inc., 2004. 
[48] Metcalf and Eddy, Wastewater Engineering: Treatment \& Reuse, 4thed, Tata McGraw-Hill, 2003.

[49] R.A. Gerhardt, Leachate attenuation in the un- saturated zone beneath three sanitary landfills in Wisconsin, Wisconsin Geological and Natural History Survey, Information Circular 35, 1977, 93.
[50] K.R. Waybrant, D.W. Blowes, and C.J. Ptacek, Selection of reactive mixtures for the prevention of acid mine drainage using porous reactive walls. Proceed of Sudbury 95, Conference on Mining and the Environment, 1995, 945-953.

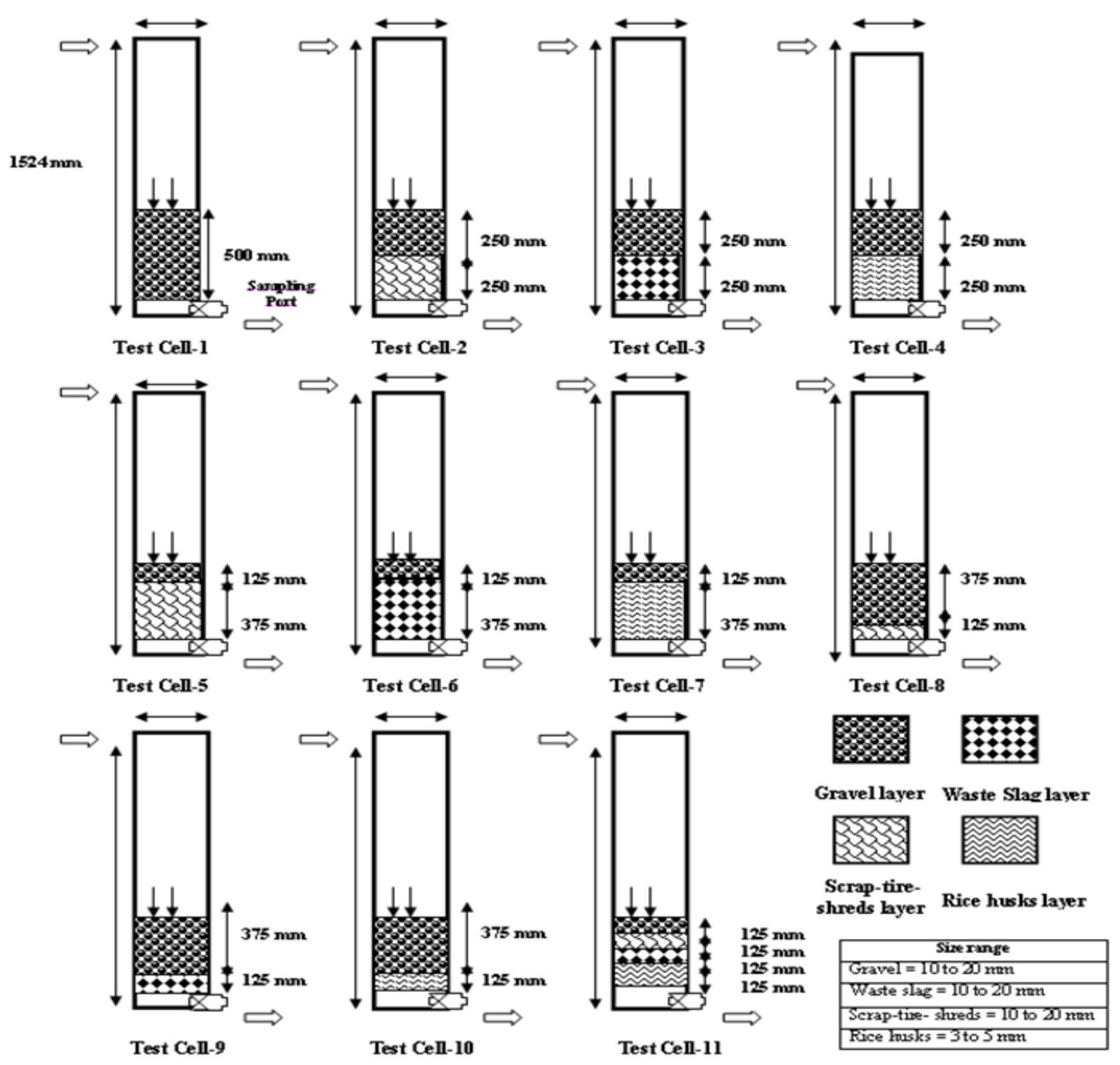

Fig- 4: Schematic representation of the experimental setup of Test Cells 1 to 11 


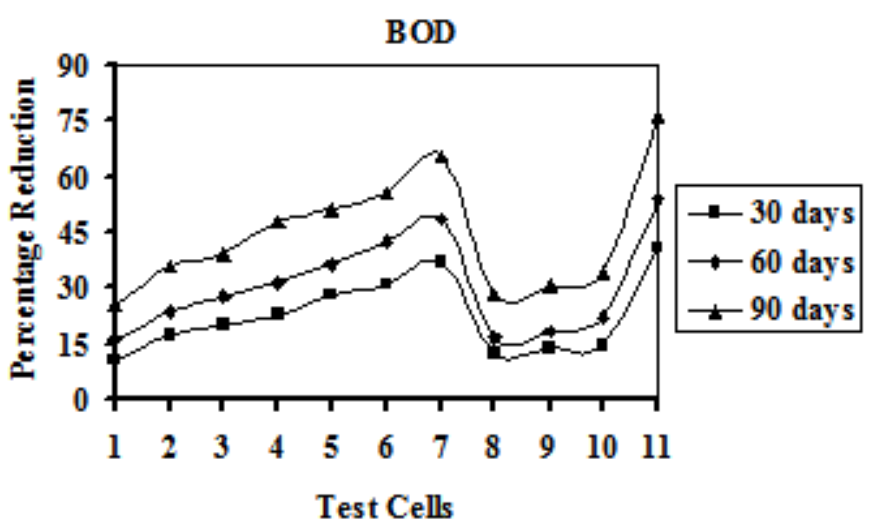

(a)

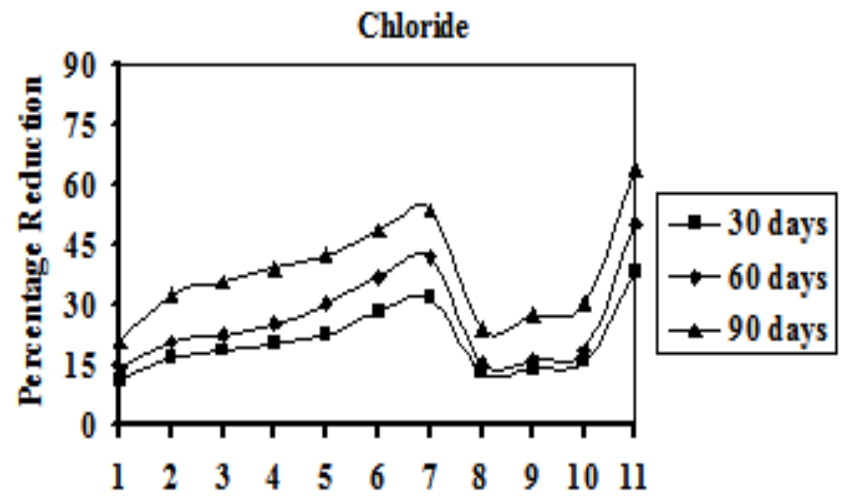

Test Cells

(c)

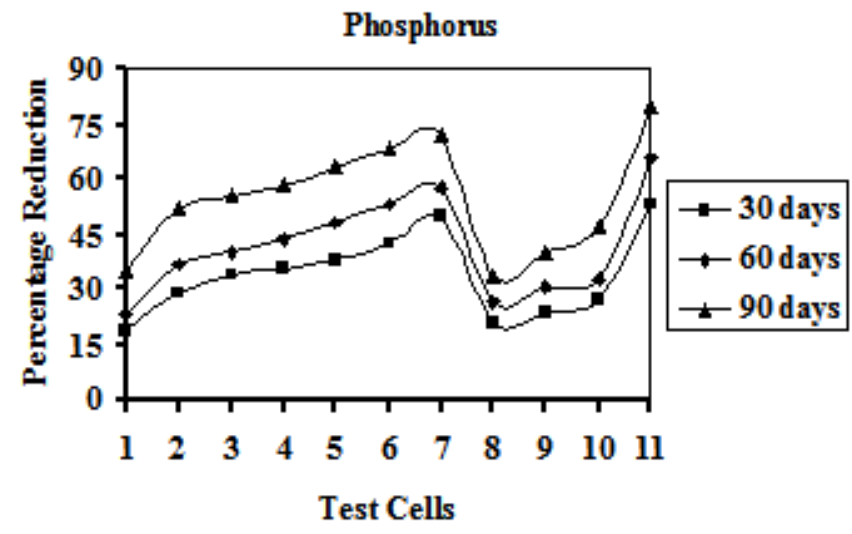

(e)

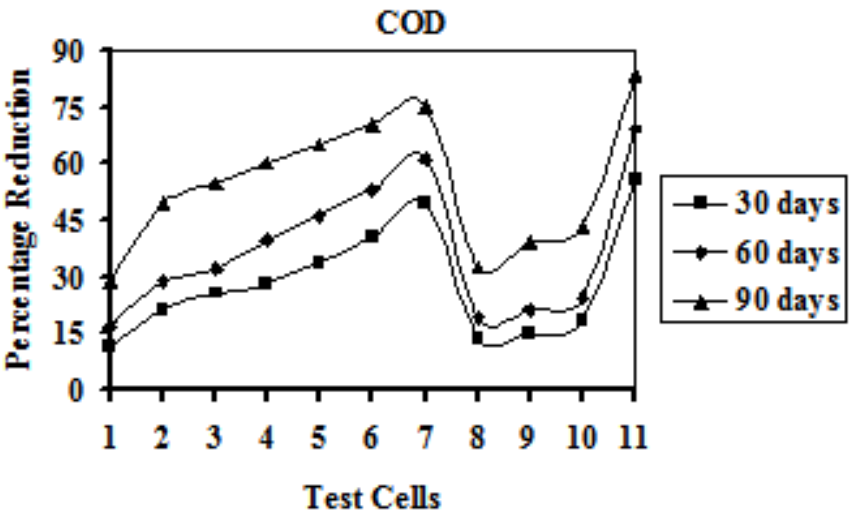

(b)

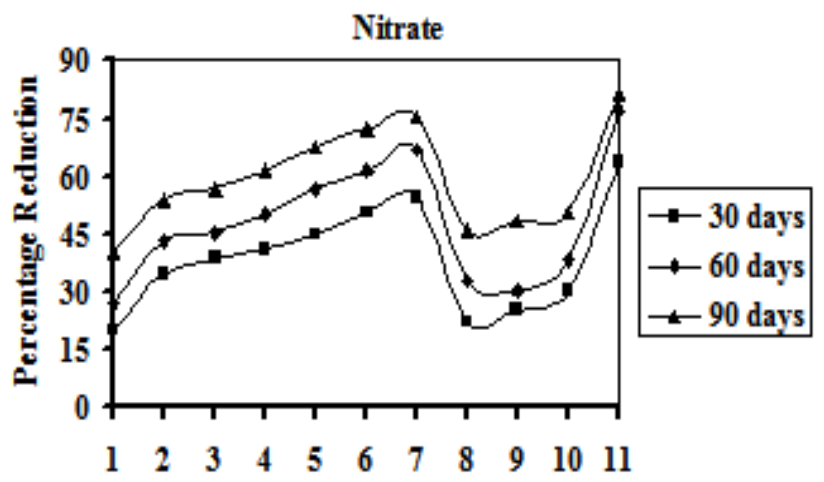

Test Cells

(d)

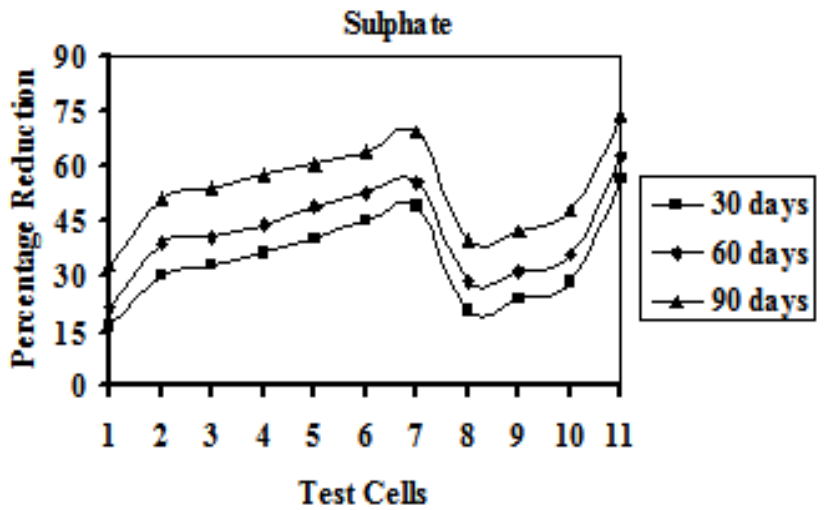

(f)

Fig- 5 (a-f): Percent reduction in leachate parameters $v s$ Test Cells- 1 to 11 after 30, 60 and 90 days 